\title{
SISTEM INFORMASI PEMBELIAN DAN PENJUALAN ROTI PADA DARBOY BAKERY
}

\author{
Siska Irawati ${ }^{1)}$, Lauw Li Hin ${ }^{2)}$ \\ ${ }^{1}$ Sistem Informasi, Fakultas Teknologi Informasi, Universitas Budi Luhur \\ ${ }^{1,2} \mathrm{Jl}$. Raya Ciledug, Petukangan Utara, Kebayoran Lama, Jakarta Selatan 12260 \\ E-mail : $\underline{\text { siskairawati.ini@gmail.com }}^{1)}$, lihin@budiluhur.ac.id ${ }^{2)}$
}

\begin{abstract}
Abstrak
Darboy Bakery merupakan salah satu usaha bisnis kuliner menyediakan bermacam - macam olahan yang diolah dengan bahan baku menjadi makanan berupa roti. Darboy Bakery merupakan toko roti yang memproduksi dan menjual makanan terbuat dari tepung yang dipanggang dalam oven seperti roti manis,roti tawar,roti buaya, dan bermacam macam rasa roti. Pengolahan bakery roti ini berjalan selama setahun dan pelayanan administrasi masih konvensional terutama pada pembelian bahan-bahan baku, penjualan roti, dan sering kali menimbulkan masalah. Dengan Adanya sistem terkomputerisasi pembelian bahan baku dan penjualan bakery akan sangat membantu untuk proses bisnis didalam darboy bakery sehingga akan menjadi lebih efektif dan efisien dalam mendukung kegiatan pembelian dan penjualan terutama laporan operasional darboy bakery. Usaha bisnis ini mengalami kendala dalam proses bisnis. Ketidakpastian dalam pencatatan persediaan stok bahan baku dan stok barang jadi. Pencatatan dalam pembelian bahan baku dan penjualan roti secara manual. Rancangan sistem informasi mengenai Bisnis pembelian dan penjualan roti. Rancangan informasi ini menggunakan Ms.Visual Basic menggunakan model UML (Unifield Modeling Language) use case diagram, activity diagram, dan sequence diagram. Model data konseptual dalam sistem informasi pembelian dan penjualan ini menggunakan database relational yaitu ERD (Entity Relationship Diagram), LRS (Logical Record Structure) dan spesifikasi basis data yang digunakan dalam perancangan basis data.
\end{abstract}

Kata kunci: Sistem Informasi,Management, Rancangan Sistem

\section{PENDAHULUAN}

\subsection{Latar Belakang}

Darboy Bakery merupakan toko roti yang memproduksi dan menjual makanan terbuat dari tepung yang dipanggang dalam oven seperti roti manis,roti tawar,roti buaya, dan bermacam macam rasa roti. Pengolahan bakery roti ini berjalan selama setahun dan pelayanan administrasi masih konvensional terutama pada pembelian bahan-bahan baku, penjualan roti, dan sering kali menimbulkan masalah. Dengan Adanya sistem terkomputerisasi pembelian bahan baku dan penjualan bakery akan sangat membantu untuk proses bisnis didalam darboy bakery sehingga akan menjadi lebih efektif dan efisien dalam mendukung kegiatan pembelian dan penjualan terutama laporan operasional darboy bakery. Adapun masalah yang berjalan saat ini, kurang mendukung efektifitas dan efisiensi Darboy Bakery, Adapun masalah-masalah yang Ada dalam sistem yang berjalan ini sebagai berikut:

a. Kurangnya informasi untuk mengetahui jumlah stok barang, owner sulit untuk merestock barang yang telah habis.

b. Tidak adanya rekap barang yang habis terjual, sehingga owner sulit mengambil keputusan untuk menambah jumlah stok barang yang diminati konsumen.

c. Tidak ada laporan untuk mengetahui transaksi pengeluaran dan penerimaan kas. d. Tidak adanya informasi mengenai laporan jurnal umum sehingga pemilik tidak dapat mengetahui laporan pendapatan.

Tujuan penulisan yang ingin dicapai dengan dibuatnya sistem terkomputerisasi ini oleh penulis, antara lain :

1. Menangani masalah-masalah yang dalam proses pencatatan pembelian dan penjualan pada darboy bakery

2. Memudahkan petugas dalam bekerja, Untuk mendapatkan data secara cepat dan akurat dalam pencarian data pencatatan.

3. Memudahkan petugas dalam pembuatan laporan.

\subsection{Manfaat Penulisan}

Manfaat dari penulisan diharapkan Agar dapat menyampaikan dan memberikan bahan masukan kepada Darboy Bakery dalam bentuk alternatif model rencana penerapan sistem informasi penjualan dan pembelian.

\subsection{Batasan Masalah}

Batasan permasalahan, maka penulis mengusulkan Rancangan Sistem Informasi Pembelian dam Penjualan Roti pada "Darboy Bakery" yang masih manual menjadi sistem 
terkomputerisasi. Sebagai berikut yang dibahas adalah:
1. Entry Pelanggan
2. Entry Barang
3. Entry Supplier
4. Entry data rekening
5. Entry data PO
6. Entry nota pembelian
7. Cetak nota penjualan
8. Entry pembayaran
9. Cetak laporan Stok
10.Cetak laporan penjualan
11.Cetak laporan pembelian
12.Cetak laporan jurnal umum
13.Cetak laporan jurnal pembelian
14.Cetak laporan jurnal penjualan
15.Cetak laporan rekapitulasi

\section{PENELITIAN SEBELUMNYA \\ 2.1. Konsep Dasar Sistem}

Sistem informasi (information system) adalah kombinasi teratur dari orang-orang, perangkat keras (hardware), perangkat lunak (software), jaringan komunikasi, dan sumber daya data yang mengumpulkan, mengubah, dan menyebarkan informasi dalam sebuah organisasi”.

\subsection{Konsep Dasar Analisa Sistem}

Menurut peneliti [4] Sistem informasi adalah kombinasi terorganisasi apapun dari manusia, perangkat keras, perangkat lunak, jaringan komunikasi, sumber data dan kebijakan serta prosedur yang terorganisasi yang menyimpan, mengambil, mengubah, dan memisahkan informasi dalam sebuah organisasi.

\subsection{Teori Pendukung}

a. Pengertian Pembelian

Menurut peneliti [1] pembelian adalah suatu sistem kegiatan dalam perusahaan untuk pengadaan barang yang diperlukan oleh perusahaan.” Menurut Hall "pembelian adalah tanggung jawab untuk memesan persediaan dari berbagai pemasok ketika tingkat persediaan jatuh ke titik pemesanan ulang”.

b. Pengertian Penjualan

Menurut [2] penjualan adalah pendapatan lazim dalam perusahaan dan merupakan jumlah kotor yang dibebankan kepada pelanggan atas barang dan jasa.

\subsection{Refrensi jurnal}

a. penelitian dalam judul "Sistem informasi pengolahan data pembelian dan penjualan pada toko kolongcucu. Diterbitkan oleh jurnal IJIS (Indonesian Journal on Information System) dengan nomor jurnal ISSN 2548-6438. Program Studi Komputerisasi Akuntansi,Politeknik Sains dan Teknologi Wiratama Maluku Utara[5].Rancang Bangun aplikasi penjualan dan pembelian barang pada koperasi Kartika samara grawira prabumulih. Ana Naela Nurhayati Fakultas Komputerisasi Akuntansi, Perguruan Tinggi STMIK Prabumulih,Ahmat Josi ,Nur Aini Hutagalung Fakultas Komputerisasi Akuntansi, Perguruan Tinggi STMIK Prabumulih. Vol 7 No 2 (2017): Jurnal Teknologi dan Informasi (JATI). Nomor jurnal : E-ISSN 2655-6839.[6]

\section{METODE PENELITIAN}

Penyusunan penelitian ini, terdapat prosesproses yang akan dilakukan dalam identifikasi kebutuhan pada Darboy Bakery :

a. Memahami masalah merupakan tahapan dari kegiatan penelitian terhadap permasalahan yang dihadapi Darboy Bakery.

b. Masalah pada proses bisnis berjalan dengan beberapa sebab akibat yang digambarkan dengan fishbone diagram.

c. Mengidentifikasi masalah pada Darboy Bakery dari hasil wawancara dan dokumen yang berkaitan dan menggunakan Activity Diagram.

d. Dengan model data dengan UseCase Diagram dan Aktivity Diagram untuk menggambarkan hasil identifikasi kebutuhan.

\section{HASIL DAN PEMBAHASAN}

\subsection{Analisis Sistem}

a. Profil Organisasi Darboy Bakery

Darboy bakery sebuah toko roti yang telah berdiri sejak Juni 2018 dari sebuah proses percobaan pembuatan roti manis kecil hingga menjadi bentuk yang besar. Dari pabrik roti rumahan yang kecil sampai dapat terbilang berjalan dengan lancar sampai saat ini.Darboy bakery kini memiliki 9 tenaga kerja yang beralamat di Rawalumbu bekasi.

b. Analisis Sistem Berjalan

\section{1) Proses Bisnis dan Activity Diagram Berjalan}

Proses bisnis yang berjalan pada Darboy Bakery adalah sebagai berikut:

a. Proses Pembelian bahan baku

Bagian gudang menginformasikan bahan baku yang dipesan kepada admin untuk melakukan proses pemesanan bahan baku admin membuatkan catatan pemesanan pembelian bahan baku ke supplier, 
setelah supplier menerima orderan mereka membuatkan kwitansi pembayaran dan mengirim barang yang dipesan, terima oleh bagian gudang beserta faktur pembayaran akan diberikan kepada bagian keuangan untuk segera dibayarkan ke supplier, setelah dibayarkan oleh bagian keuangan kemudian mendapatkan kwitansi pembayaran pembelian dari supplier.

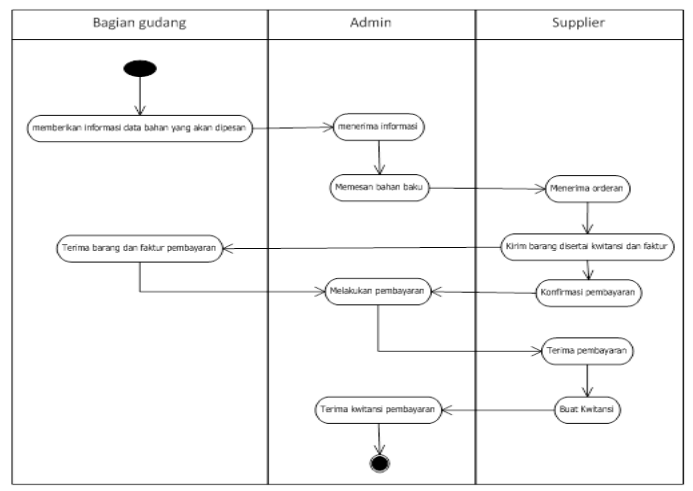

Gambar 1. Proses Pembelian bahan baku

Pada gambar 1 terdapat aktivity diagram pembelian bahan baku

b. Proses penerimaan pembelian bahan baku

Supplier mengirimkan bahan baku ke bagian gudang darboy bakery.tanda terima bahan baku diterima oleh bagian admin darboy bakery.

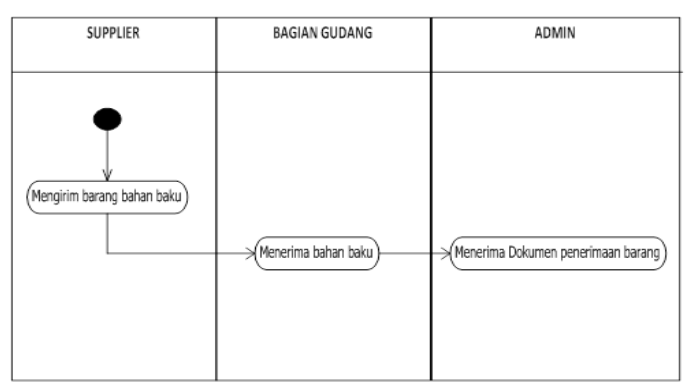

Gambar 2. Proses Penerimaan bahan baku

Pada gambar terdapat activity diagram penerimaan bahan baku

c. Proses Pencatatan Penjualan

Bagian Gudang setiap hari menghitung persediaan stok bahan baku roti, mencatat pemesanan bahan baku roti, mencatat persediaan stok roti kemudian catatan diberikan ke bagain admin.Admin mencatat pengeluaran roti ke customer,membuatkan list untuk customer, bagian keuangan/ kasir menyerahkan kwitansi pembayaran kepada customer. Kemudian admin melaporkan hasil penjualan kepada owner darboy bakery setiap bulannya.

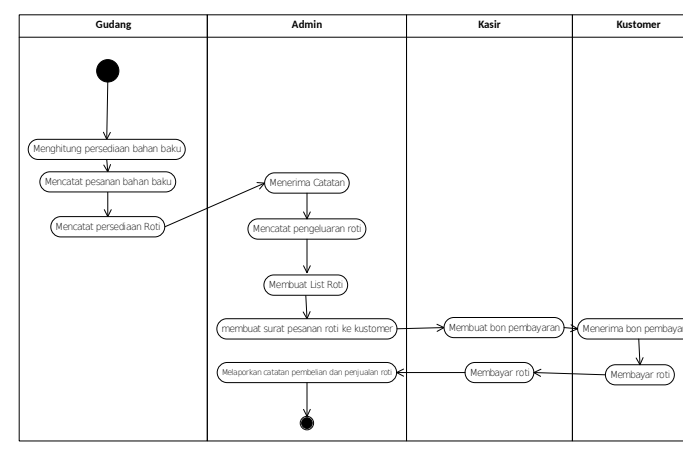

Pada gambar 3 terdapat pencatatan penjualan

d. Proses Pemesanan dan pengiriman

Marketing melakukan penawaran Darboy Bakery kepada pelanggan, jika Pelanggan tertarik pelanggan bisa datang langsung ke toko Darboy Bakery atau via telepon. Pelanggan memilih Roti yang ingin dibeli. karyawan mencatat pesanan ke dalam nota pembayaran yang berisikan nama roti,harga satuan roti dan jumlah pemesanan dan total harga yang harus dibayar pelanggan. Jika pesanan dikirim melalui driver darboy bakery maka akan dikirim sesuai dengan PO (Purchase Order).

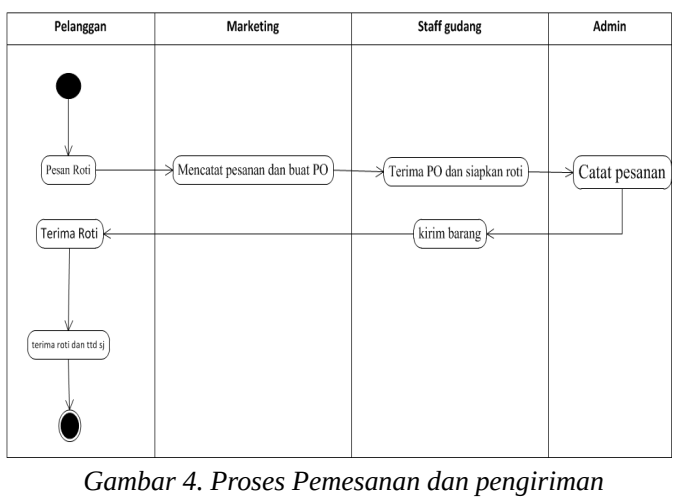

Pada gambar 4 terdapat pemesanan dan pengiriman roti

e. Proses Pembayaran

Apabila barang telah siap dikemas maka pelanggan langsung melakukan pembayaran di tempat dan proses ini disebut juga dengan pembayaran tunai / cash. Bagian Kasir akan membuat nota pembayaran. Selanjutnya karyawan akan menyerahkan barang dan bukti pembayaran .

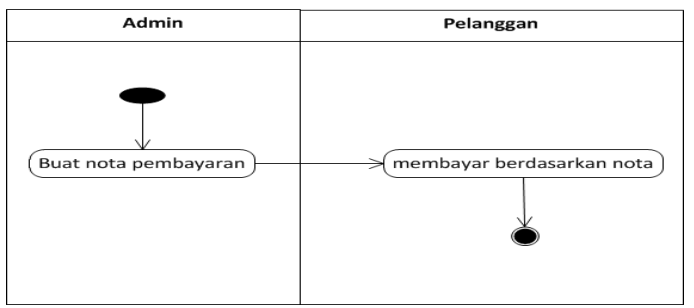

Gambar 5. Proses Pembayaran 
Pada gambar 5 terdapat proses pembayaran penjualan roti

f. Proses Laporan

Setiap akhir bulan bagian administrasi selalu membuat seluruh laporan berdasarkan data yg dicatat setiap hari dan direkap setiap bulan yang diserahkan kepada pimpinan/owner.

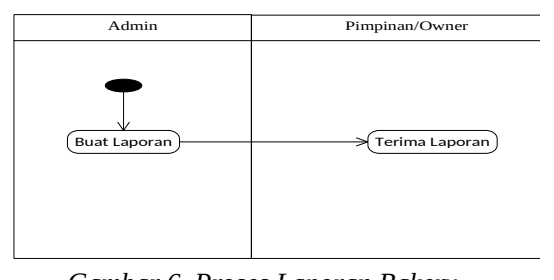

Famhar 6 Proses Ianoran Rakerv

Pada gambar 6 terdapat laporan bakery roti kepada pemilik usaha

\subsection{Analisa Masalah (Fishbone Diagram)}

Menganalisa masalah Sebab-akibat yang ada dapat dilihat gambar sebagai berikut :

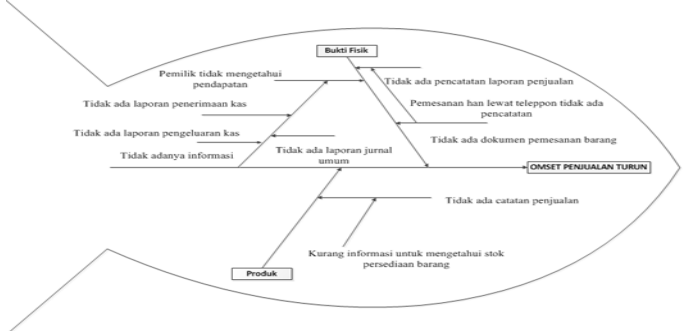

Gambar 7. Fishbone Diagram dalam usaha roti

Pada gambar 7 terdapat diagram fishbone

\subsection{Perancangan Sistem}

1) Usecase Diagram

a. UseCase Diagram (Master)

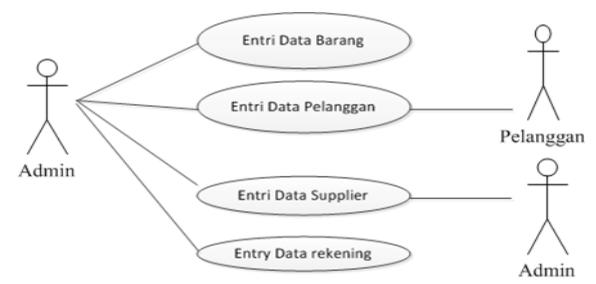

Gambar 8. Use Case Diagram Master master

Pada gambar 8 terdapat Usecase diagram

b. Use Case Diagram (Transaksi)

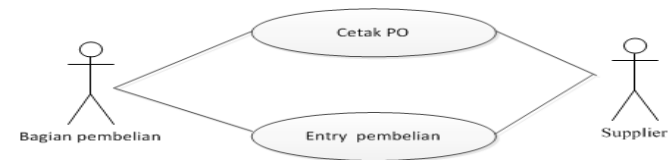

Gambar 9. Use Case Diagram Transaksi pembelian
Pada gambar 9 terdapat use case diagram transaksi pembelian

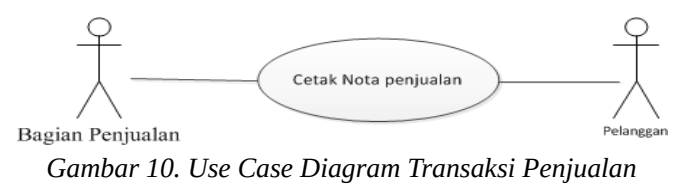

Pada gambar 10 terdapat use case diagram transaksi penjualan

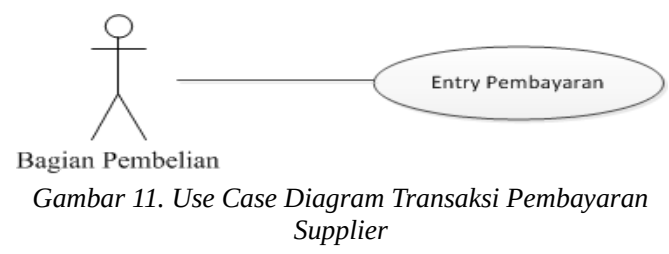

c. Use Case Diagram (Laporan)

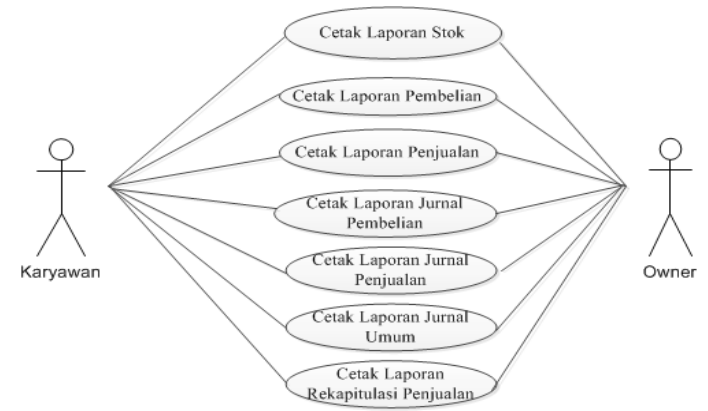

Gambar 12. Use Case Diagram Laporan

Pada gambar 12 merupakan use case diagram beberapa laporan

2) Entity Relationship Diagram

Dalam bentuk ERD model data dapat diberikan sebagai berikut :

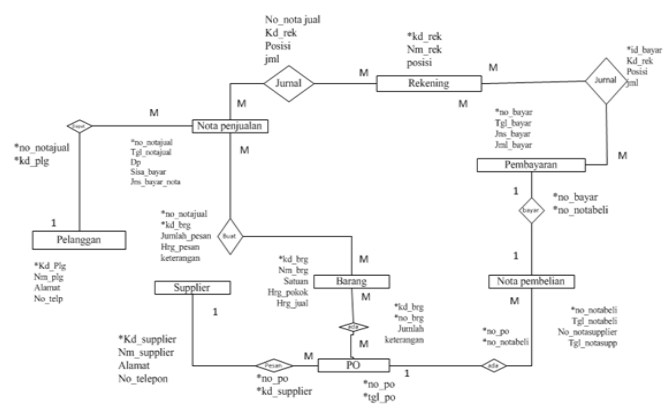

Gambar 13. Entity Relationship Diagram (ERD)

Pada gambar 13 merupakan erd dalam proses bisnis

3) Stuktur Menu Sistem 


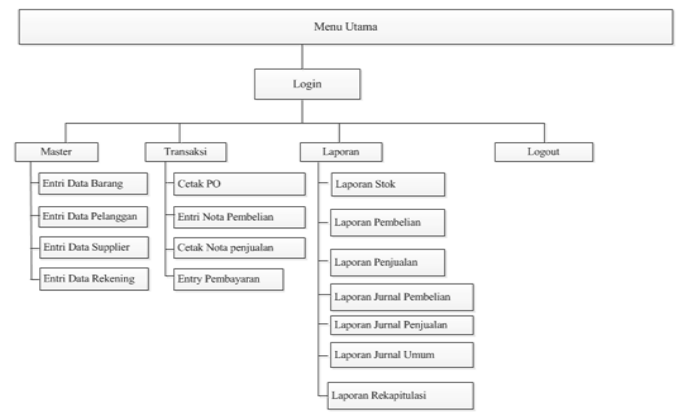

Gambar 14. Struktur Menu

Pada gambar 14 terdpata struktur menu dalam sistem yang dibuat

4) Rancangan Layar

a. Rancangan Layar Entri Data Barang

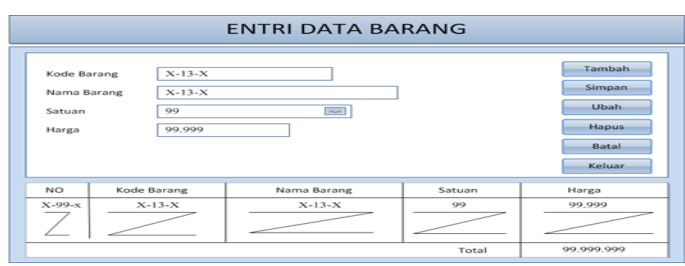

Gambar 15. Rancangan Form Entri Data Barang

Pada gambar 15 merupakan rancangan form entri data dari sistem yang dibuatkan

b. Rancangan Layar Form Pelanggan

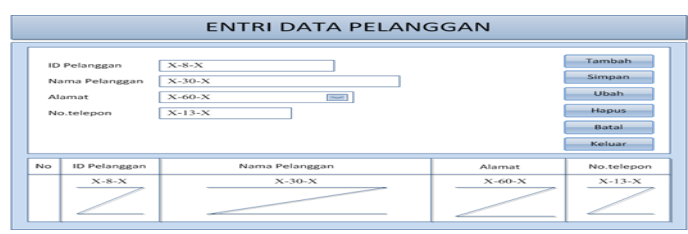

Gambar 16. Rancangan Form Pelanggan

Pada gambar 16 terdapat form yang dibuat dalam sistem yang dibuatkan

c. Rancangan Layar Form Entri Data Supplier

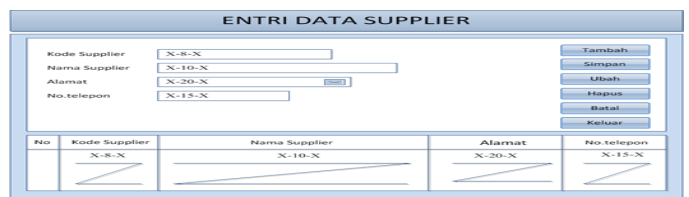

Gambar 17. Rancangan Form Entry Data Supplier

d. Rancangan Layar Form Cetak PO

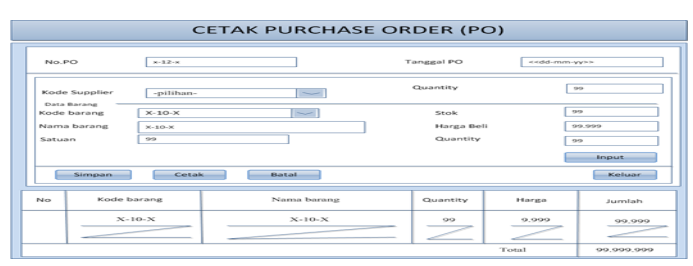

Gambar 18. Rancangan Form Cetak PO
Pada gambar 18 merupakan suatu rancanagan dari sistem form cetak PO

e. Rancangan Layar Form Entri Pembelian

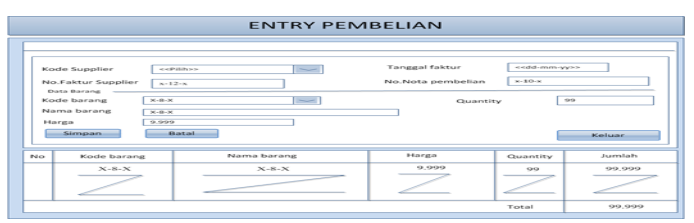

Gambar 19. Rancangan Form Entri Pembelian

Pada Gambar 19 merupakan suatu rancangan form entri pembelian

f. Rancangan Layar Form Cetak Penjualan

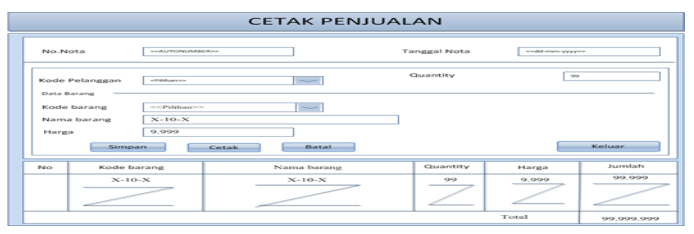

Gambar 20. Rancangan Form Cetak Penjualan

Pada Gambar 20 merupakan suatu rancangan cetak penjualan

g. Rancangan Layar Form Entry Pembayaran

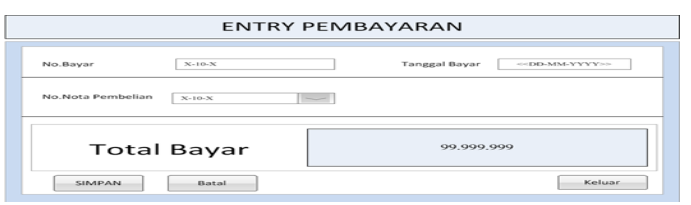

Gambar 21. Rancangan Form Tanda Terima Barang

h. Hasil Cetak Laporan Pembelian

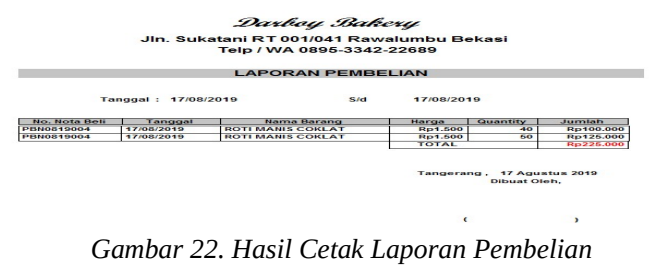

Pada gambar 22 merupakan hasil cetak dari laporan pembelian

i. Hasil Cetak Laporan Penjualan

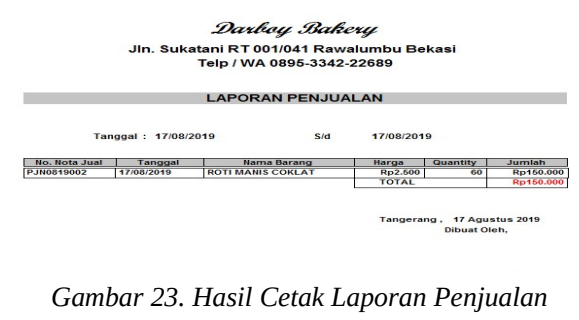

Pada gambar 23 merupakan hasil dari cetakan sistem 


\section{KESIMPULAN}

Kesimpulan sebagai berikut adalah :

a. Sistem yang sudah terkomputerisasi, memudahkan untuk mengetahui data stok secara tepat dan akurat.

b. Dengan sistem terkomputerisasi memudahkan dalam proses pembuatan laporan. sehingga pemimpin mendapat laporan yang diinginkan dengan cepat dan akurat.

c. Mempercepat dalam membuat laporan pembelian dan penjualan, karena sudah dibuatkan modul sistem yang dapat mencetak laporan sesuai periode yang diinginkan.

d. Mempermudah dalam proses pencarian bukti pembayaran karena telah dibuatkan modul sistem yang dapat menyimpan bukti bayar.

e. Dengan adanya sistem yang sudah terkomputerisasi, dibuatkan modul sistem untuk mencetak laporan rekapitulasi, sehingga pemimpin dapat mengetahui perkembangan perusahaan.

\section{DAFTAR PUSTAKA}

[1] Sujarweni, V.W. Sistem Akuntansi. Yogyakarta: Pustaka Baru Press, 2015.

[2] H. Simamora. Manajemen Sumber Daya Manusia. Yogyakarta : STIE YKPN. 2010

[3] Yakub. Pengantar Sistem informasi. Yogyakarta: Graha Ilmu, 2012

[4] James A.O'Brien and George M.Marakas, Analisis Sistem Informasi / Tata Sutabri Ed. I. Yogyakarta : Andi, 2016

[5] Muhdar Abdurahman dalam jurnal penelitian dalam judul "Sistem informasi pengolahan data pembelian dan penjualan pada toko kolongcucu. Diterbitkan oleh jurnal IJIS (Indonesian Journal on Information System) dengan nomor jurnal ISSN 2548-6438. Program Studi Komputerisasi Akuntansi,Politeknik Sains dan Teknologi Wiratama Maluku Utara.

[6] Ana Naela Nurhayati Fakultas Komputerisasi Akuntansi, Perguruan Tinggi STMIK Prabumulih,Ahmat Josi ,Nur Aini Hutagalung Fakultas Komputerisasi Akuntansi, Perguruan Tinggi STMIK Prabumulih. Vol 7 No 2 (2017): Jurnal Teknologi dan Informasi (JATI). Nomor jurnal : EISSN 2655-6839 